Annual Review of Applied Linguistics (1992) 12, 156-171. Printed in the USA. Copyright $(\subseteq) 1992$ Cambridge University Press 0267-1905/92\$5.00+.00

\title{
ADULT LITERACY ISSUES IN CANADA
}

\author{
Barbara Burnaby
}

\section{$\underline{\text { INTRODUCTION }}$}

This chapter concerns adult literacy issues in Canada-adults being defined as people fifteen years or older and out of school-and focuses primarily on adults who are not (or are barely) literate in any language. Until the mid1980s, educational support for adults who wished to develop or improve their literacy skills up to about the grade eight level was almost entirely a charitable endeavor. People with low literacy skills were perceived to be a marginal group consisting of elderly people who had not had the chance to go to school, people with disabilities who were considered to be untrainable, certain immigrant populations, and people who had failed in the school system through some individual weakness. In 1985, in the midst of national concerns about the productivity of the country's labor force, the government of Ontario launched a program of funding for three explicit purposes: 1) to assist literacy programs for adult learners, 2) to support literacy organizations, and 3) to fund a small amount of community based research on adult literacy. The federal government followed suit in 1986, establishing the National Literacy Secretariat in the Department of the Secretary of State for Canada. For constitutional reasons, the Secretariat does not fund adult literacy services directly. Part of its mandate has been to get provinces and territories to undertake adult literacy action. It also supports the promotion of research on literacy programs. Adult literacy has thus been catapulted onto government agendas, and private and public institutions of all sorts have jumped on the bandwagon.

In terms of internationally accessible publications on adult literacy research and activities in Canada, the recentness of these developments means that print materials on this topic are still largely of the ephemeral sort and that academic research is just beginning to address questions raised by public and private sector institutions and the public at large. The following review of 
literature from 1985 on is skewed in favor of material that can be fairly easily obtained from outside the country. Also, since the topic is highly complex and has been discussed in print from the points of view of many interested parties, certain issues will only receive limited coverage with selected examples being cited for illustration purposes.

\section{DEFINITIONS OF LITERACY}

It appears to be almost obligatory that any piece of writing on adult literacy begin with a discussion on how difficult it is to define literacy, as well as an account of the history of literacy definitions. A common and productive theme in recent discussions is that concepts of literacy are embedded in complex psychological, linguistic, and social contexts. De Castell, Luke and MacLennan (1986), writing about literacy in both children and adults, criticize technocrats and progressives alike for creating education and testing approaches that serve narrow, behavioristically oriented ends and foster the impression that there is a literacy crisis. They suggest that workable definitions of literacy must take into account historical factors, competence in social contexts, and insights from communications theory.

Sharing these concerns to some extent, Hautecoeur (1989a) has argued that three lacunae in our general understanding of illiteracy are particularly problematic: 1) a minimal concern for writing skills development, 2) an inability to perceive the points of view of those considered to be illiterate, and 3) a disregard for the social contexts of communication. Each of these problems have hindered not only our conceptualization of, but also our practical approaches to adult literacy issues. Norman and Malicky (1986) revealed that low-literacy-skill adults regard their own concepts of "reading" related more to word identification than to comprehension, much less to an awareness of wider contexts. Darville (1989) argues that an appreciation of the complexity of literacy as a phenomenon must be married to the Freirean concept of empowerment if adult literacy work is to be framed and carried out effectively. If agreement is hard to reach in terms of an operational definition of literacy, at least a review of the literature can provide some principles, often pointing to what is not a useful definition (Thomas 1989). In another review of the literature on definitions of literacy, Bell (1991) produced the concept of four "commonplaces" of literacy (user, text, society, and process) which must be taken into account if the full complexity of literacy is to be addressed. Bell convincingly demonstrates the utility of her concept by applying it to an analysis of three cannonical works in the field of literacy.

\section{POLICY OVERVIEWS AND SURVEYS}

In 1985, Wagner published an article surveying statistical information on adult literacy levels in Canada, government programs for literacy development, and literacy teaching and practice. He called for research which would identify 
the extent of adult illiteracy, the real problems associated with it, and effective strategies in the field. He also criticized governments for leaving adults with low levels of literacy-a significant group in the population-disenfranchised. A few of Wagner's questions were answered in 1987 when the Creative Research Group and the Southam Newspaper Group published the results of a survey commissioned by Southam on adult literacy in Canada. A test, loosely based on the National Assessment of Educational Programs (NAEP) of the Educational Testing Service in New Jersey, was administered to over 2,000 adults, and the analysis indicated that 4.5 million adults ( 24 percent of the population) were functionally illiterate. Within this group, 1.5 million or 8 percent of the population were considered to be profoundly illiterate (Creative Research Group 1987). Southam published a journalistic account of the results along with material from literacy learners, adult literacy educators, and others, though this account served to shed somewhat more heat than light on the survey results (Calamai 1987). There were a number of criticisms of the survey; many were technical in nature and focused on test construction issues, but some, such as Olson (1988), condemned the test on the basis that one test could not possibly reflect the complex nature of literacy. Rather, he argued that such misrepresentations of literacy problems could hamper literacy advancement.

The National Literacy Secretariat in cooperation with Statistics Canada followed up on the Southam Survey in 1989 with a much larger survey (about 9,500 respondents), again using an instrument derived from the NAEP, but one which permitted finer distinctions of literacy levels in the areas of reading, writing, and numeracy than did the Southam test (National Literacy Secretariat and Statistics Canada 1990). Its basic findings generally confirm those of the Southam survey. This survey is significant particularly because of its scale. Unfortunately, at the time of writing this article, public information is available mainly in press release format although the preparation of detailed discussion papers is in progress.

In 1988 the Council of Ministers of Education, Canada (CMEC) published a report on English and French adult literacy including a review of documents (mostly government reports) and a discussion of national needs. While presenting somewhat sanitized material, its usefulness lies in a description of provincial adult literacy programs (Cairns 1988). L'Institut Canadien d'éducation des adultes and la Fédération des Francophones hors Québec collaborated on a similar report on literacy among francophone adults in Canada. Like the $\mathrm{CMEC}$, it gives an overview of provincial situations. The discussion is somewhat enlivened by two controversial facts: 1) French, outside of Quebec and New Brunswick, has marginal status even though it is one of Canada's official languages; and 2) the Southam survey found francophones to score somewhat lower in general on literacy than their anglophone counterparts (Boucher 1989). After conducting a survey of the literature, Wagner (1989a) has criticized the quantity 
and quality of research in French into literacy in Canada and claims that these problems are inhibiting the development of measures to combat illiteracy.

Thomas, Taylor and Gaskin (1989) discuss the role of the federal government, as opposed to the provincial governments, in adult basic education, documenting the federal government's contention that they have provided much more leadership in this area than have the provincial governments, even though the provincial governments constitutionally have jurisdiction over education. This perspective complements the surveys of Cairns and Boucher and provides much more historical detail. Anderson (1989) also offers a succinct, factual overview of programs in adult basic education provided by the federal and provincial governments and two large literacy agencies. More recently, Wagner and Grenier (1990) have published a carefully documented study of literacy among francophones in Ontario with an emphasis on the interrelationship between the culture of illiteracy and the culture of francophones as a linguistic minority in the Ontario context. Darville (in press) scrutinizes the roles that universities play and could play in training literacy practitioners, measuring literacy levels, doing research on approaches to literacy teaching, and analyzing policy from the perspective of the social and economic paradigms that shape university priorities.

\section{LITERACY AND ITS IMPACT ON CANADIAN INSTITUTIONS}

People in Canada with low levels of education tend to take the least advantage of educational opportunities in adulthood. A Statistics Canada survey in 1983 indicated that 40 percent of university graduates took some kind of formal education course in that year while only 5 percent of those with less than grade 9 education participated (Devereaux 1985:13). Of the respondents classified as functionally illiterate in the Southam survey, only 10 percent said that they might take remedial instruction, but half indicated that they needed help in some literacy tasks (Calamai 1987). A further analysis of the Statistics Canada data by the Canadian Association of Adult Education, reported on in Devereaux (1985), showed that adults with low levels of formal education had different preferences for the kinds of educational delivery agencies they would attend than did their more highly educated counterparts (see also Canadian Association for Adult Education 1985: 155-189). Those with zero to eight years of education preferred voluntary organizations and school boards, and avoided colleges and universities, while those with at least some post secondary education showed almost the opposite trend of choices.

As stated at the outset, until recently adult literacy work in Canada has mainly been left to charitable, voluntary organizations, and they still comprise the majority of providers although they increasingly work in partnership with other kinds of institutions. (See Gaber-Katz and Watson 1989, Miller 1987, and Moore and Westell 1989 for discussion on the roles of community based, volunteer oriented programming.) Boards of education have had a long history of 
involvement with adult basic education, and this involvement has increased markedly in recent years (e.g., the Board of Education for the City of Toronto 1985). Community colleges, which are a relatively recent phenomenon in Canada, have begun to take initiatives in adult basic education either to help potential students qualify for and succeed in regular college programs, or to run special adult basic education programs funded by governments. In order to assist colleges in planning for adult literacy work, the Association of Canadian Community Colleges has developed a database on information about literacy programs across the country (Association of Canadian Community Colleges n.d.); predictably, its content is weighted towards programs in colleges. Especially with the rise in profile of adult literacy concerns and the availability of government funding, traditional educational institutions such as school boards and community colleges have also had to consult the expertise of the community agencies to develop literacy programs. In fact, the terms of a good deal of government funding encourage cooperation between community agencies and educational institutions. Shuttleworth (1989) describes the development of adult basic education offerings at one school board, highlighting ways in which cooperation was developed with a variety of other agencies. Voluntary agencies whose main work is not focused on education have been influenced by the heightened profile of adult literacy concerns. A survey of seven agencies published in 1991 (e.g., the John Howard Society, One Voice-The Canadian Seniors' Network, the Salvation Army) indicates ways in which adult literacy issues affect their operations and how they have responded (Godin 1991).

The shift in educational funding priorities toward adult literacy, work, and the realignment of relationships among educational institutions and voluntary agencies clearly has a strong economic motivation. One indication of such motivation is the large amount of publicity and the growing number of publications on literacy in the workplace relative to other kinds of literacy work. A number of non-governmental organizations oriented to business and economics have recently published reports (e.g., Drouin 1990, Economic Council of Canada 1990) which all stress the following issues:

1. changes are occurring in the structure of the world economy with attendant consequences for the Canadian labor force;

2. concerns have been raised about the preparation of Canada's labor force for the flexibility that will be required;

3. a conviction is widely felt that things will get worse before they get better;

4. a recognition is growing that organizational cultures will need to develop a value for lifelong learning.

The Canadian Business Task Force on Literacy commissioned a study of the cost to business brought about by illiteracy in the workplace. This report indicated that $\$ 4.5$ billion was lost to business and $\$ 11$ billion to Canadian society 
as a whole as a result of illiteracy, but these figures are highly speculative since they were extrapolated from other basic economic data (Canadian Business Task Force on Literacy 1988). In a survey of human resources managers/general managers of 626 Canadian companies with more than 50 employees, 70 percent of the respondents felt that they had a significant problem with functional illiteracy in some part of their organization; 25 percent indicated that illiteracy slowed down the introduction of new technology; and 34 percent reported that it impeded training and the acquisition of new skills (Conference Board of Canada, DesLauriers 1990). These are, of course, employers' perceptions only and raise questions, for example, about the quality of the training provided rather than the workers' abilities.

Jean (1989), speaking from the point of view of one provincial government, urges that pressure be put on governments to create the kind of education needed for technological change. On the other hand, in a critical overview of economic theories (human capital and screening) in relation to adult basic education, Rubenson (1989) notes that the private sector has been supporting training in high technology for skilled workers through links with higher education-the motivation being the expectation of economic benefits. In Rubenson's view, employers tend to see adult basic education for lower skilled employees as equity related, and thus the responsibility of government. However, there are economic as well as social reasons for employer-sponsored education and training for employees who work at low skill tasks.

Twenty-eight articles which explore various aspects of literacy in the workplace were recently published, edited by Taylor, Lewe and Draper (1991). Several of these articles are reports on projects that involve varying kinds of institutions. Turk and Unda (1991) report on a large government funded project that supports the Ontario Federation of Labour in promoting literacy in unionized workplaces. In these settings, adult basic education and English as a second language programs are set up and taught by co-workers; management is only involved at its own discretion. Workers in the program set their own objectives, and the focus is on empowerment rather than literacy as a solution to all problems. With over 100 programs across Ontario, it has gained a high profile as a successful literacy initiative. In another case, a three year workplace literacy project initiated by a literacy volunteer organization had mixed results (Batdorf 1991). It introduced volunteer tutors into one industrial company in each of three regions of Canada with the cooperation of management and unions (where the latter existed). In only one site was the target met of recruiting 100 learners per year. There were problems of coordination within and outside of the literacy organization, and the project design was such that effects on productivity were not measurable. Reporting on a third project, Hawrysh (1991) describes the preliminary results of a study to assess workplace communication skills required of supervisors and production workers in the British Columbia forest industry. Cooperation between unions and managements at the provincial level resulted in 
formal interviewing and testing in ten mills. Highlights of the results thus far include development of strict measures for confidentiality of participants, cooperation between unions and managements, provisions for help for participants if they required it, and plans for follow-up. Also of note in this collection are two "how to" articles, one by Taylor and Lewe (1991) on literacy task analysis and the other by Lewe (1991) on partnerships (among management, union, worker, and outside educational resource) for workplace literacy programs.

\section{ISSUES OF ACCESS FOR LITERACY LEARNERS AS A GROUP AND FOR SPECIFIC SUB-GROUPS}

Reasons why adults in Canada with low levels of formal education are the least likely to be involved with continuing education programs is a focus of current research. A recent qualitative study by Thomas (1990a) examined potential learners' non-participation in, and drop-out from, adult basic education programs in various institutions in British Columbia. Based on detailed statistical information, she concluded that some people avoided or resisted participation because of low perceived need, persistent negative attitudes toward school, or difficult economic circumstances. Learners tended to drop out for work or family related reasons. Thomas encourages the view that learners who leave a program not necessarily be considered drop-outs since many have a history of attendance in programs at intervals. In this report, and a second one (Thomas 1990b), she offers detailed advice to adult basic-education-program deliverers on recruitment, retention, and follow-up of learners. In a rather more theoretical and politically oriented article, Hautecoeur (1989b) argues that there is a greater supply of literacy training in Quebec than there is demand for it; he accounts for this gap as sub-culture resistance to middle class literacy norms. For more than a decade, the Workers' Educational Association of Canada has been grappling with problems of access to education by conducting experiments and research into educational brokerage; this involves providing information and counseling for potential learners-especially immigrants and those with relatively low levels of education-on the appropriate educational program for their needs. A number of models of educational brokerage now have been tested and adapted to meet a variety of learner and institutional needs (Terry in press).

Material on women's access to, and experiences with, literacy learning has been abundant recently. Horseman (1990) conducted interviews with women literacy learners in rural communities in Atlantic Canada. This study shows the social structures that make personal and practical access to literacy learning difficult, the determination with which these women resist the labels applied to them by the larger community, and their dreams and plans for personal development. Lloyd (1991) conducted a focus group study with women in literacy programs in four communities across Canada in order to develop research questions for a second phase of the study (which is to be participatory action research). The results of the first phase addressed the outcomes of "woman- 
positive" and "learner-centered" approaches when administrators and staff espouse them, when research is conducted on them, and when women participate in them. An especially rich publication relating to these issues is the special double edition of Canadian Woman Studies on women and literacy (Cox and Sanders 1988). Most of the articles are only two or three pages long, but a wide range of perspectives and topics are covered.

In another area of concern, diagnostic clinics and special programs for children with learning disabilities have florished in Canada for at least a decade because of research advances in this field as well as a certain amount of political will on the parts of relevant provincial governments. Recently, the resources that served children with learning disabilites have been increasingly pressed into service to assist adults; however, it is difficult to find published reports on this topic in Canada. The report on the workplace experiment conducted in three workplaces by a voluntary literacy organization (Batdorf 1991) indicates that there was evidence of learning disabilities among the participants in the study (Cranton and Castle 1990). Thomas, in her study of participation and retention in adult basic education programs in British Columbia (1990a), identified a group of people with learning disabilities in her population of interviewees. She notes that some knew they had a learning problem but were never diagnosed; others were diagnosed but untreated. She also comments that the only diagnostic facility for adults in the province was struggling for funds and that some learners had gone to school boards for testing. Learning disabled students specifically asked for special instructional strategies to accommodate their learning needs.

Another group with special needs with respect to adult basic education is the mentally handicapped. A comprehensive book on this topic (G. Allan Roeher Institute 1990) considers issues such as defining and measuring literacy among mentally handicapped adults, the need for literacy among this group, literacy program availability, and barriers to literacy. Research for this book shows that literacy skills assist mentally handicapped individuals to participate better in community life: a lack of literacy skills in this group has a closer relationship to poverty, unemployment, and low health status than among the general population. Ex-psychiatric patients are also a special group in the adult literacy field, and research is greatly needed on the effects of psycho-active drugs and learning. A personal story of learning and medication is recounted by Jones and Brown (1988). Literacy for the deaf has been extensively covered in two reports by Carver (1989) and Carver and Robar (1990). In a review of research literature, Carver reports that over the past thirty years deaf students are consistently far behind their hearing peers in literacy. These results have significant consequences with respect to deaf students' access to higher education. He blames this fact on the deficit model approach by which most deaf youth are educated. The reports recommend, with rich documentation, institutional and curriculum approaches to remedy this situation. Addressing yet another group, One Voice, the Canadian Seniors' Network, published a report in 1989 pointing to the 
relatively low levels of education among elderly Canadians and summarizes North American research and program literature on learning and older adults. There are a number of other groups that deserve to be considered in this context, but published materials did not come to hand.

Special consideration is given here to native born Canadians and immigrants who speak neither English nor French and are not literate in any language. If and when such people gain access to an adult basic education program, it is usually under the rubric of learning English or French as a second language (ESL/FSL) rather than literacy. Unless special provision is made to accommodate their needs, they usually drop out of second language classes quickly because of the methodologies used in the classroom (Klassen 1987) or because of negative pressures from the social context in which they are living (Rockhill 1990). Indeed, a federal English-as-a-second-language program, set up to reach women not destined for the labor force, drew out a significant number of illiterate immigrants who had never before taken part in such programs because this was the first one that they found accessible (Burnaby 1988).

Additional recent studies address a number of adult language minority contexts. Klassen (1987) recounts details of the daily lives of Spanish speaking illiterates in Toronto and the meanings they attached to literacy in English and Spanish. His findings are much more detailed than those of Thomas (1990a) and Hautecoeur (1989b) in their studies of general access to literacy education, but his sample was small and highly focused. Cumming and Gill (1991) detail the results of an experimental program for undereducated Punjabi women in Vancouver involving both English and Punjabi literacy; the authors link their success in recruiting and retaining participants to special accommodations to these women's gender roles, ethnic background, and minority cultural status in the community. A special issue of TESL Talk (Bell 1990) on ESL literacy includes a forum of ten specialists responding to the question: "When a learner attempts to become literate in a second language, what is he or she attempting?" This issue included seven general articles and a number of others on methods, materials, evaluation, assessment, and planning. In centers in Canada where immigrants are concentrated, there has been a movement in the past decade to offer literacy in the mother tongue to people who are not mother tongue speakers of English or French and who are not literate in any language. The Cumming and Gill paper, mentioned above, is an example of one approach involving bilingual literacy; however, monolingual non-official-language literacy classes exist as well (Duncombe and Fournier 1987).

Finally, the linguistic history and circumstances of aboriginal peoples in Canada differs considerably from that of other native born Canadians or immigrants to this country. All but three of Canada's approximately sixty aboriginal languages are considered to be at varying degrees of extinction. Census data indicate that only 29.3 percent of ethnically aboriginal people 
reported an aboriginal language as their mother tongue in 1981 compared with 87.4 percent in 1951 (Burnaby and Beaujot 1986:36). Virtually all the rest grew up speaking English. Achievement in formal education among aboriginal Canadians averages significantly below the national norm (Hagey, Larocque and McBride 1989). For the purposes of government programs, most aboriginal Canadians are treated separately from the rest of the population. With respect to literacy, these circumstances have resulted in developments particular to aboriginal contexts. First, as a result of concern about the viability of various aboriginal languages, school and adult language programs were created starting in the $1960 \mathrm{~s}$. These programs sparked considerable academic and community debate about orthographies for the languages (Burnaby 1985). Second, as governments have created adult literacy initiatives in the past few years, aboriginal people have generally been given priority status and their own program administration. Third, because of variation among communities regarding the languages (aboriginal and official) used for various functions of communication, and because of a move to give control over decision making to communities, the rhetoric, at least, stresses the need for communities to decide the languages, methods, and groups within the community to be targeted in literacy programs. An overview of these developments and recommendations for action are provided in a report from the Parliamentary Standing Committee on Aboriginal Affairs on aboriginal literacy (Hughes 1990). This volume contains quotations from witnesses at public meetings and written submissions to the committee as well as information from the published literature.

\section{ADULT LEARNING AND CLASSROOM PRACTICE}

Material relating to teaching approaches and program development for use with low literacy adults in Canada is more often published as "how to" for teachers and administrators than as standard academic research. One exception is Fagan's (1987) experiment that involved having low literacy adults reading aloud narrative and expository passages that also varied in level of difficulty. The results indicated that the adults exhibited more meaning related processing for the narratives and more decoding for expository text; the degree of difficulty had less effect than the type of text. Educational and popularly oriented materials mainly focus on learner centered approaches such as whole language (White and Norton 1991), family literacy (O'Leary 1991), learner centered materials development (McBeth 1989), and an experiential approach to remedial work (Lohnes 1989). Examples of materials combining literacy and content teaching are the Ontario Public Health Association and Frontier College (1989) on literacy and health, and Miller (1990) on illiteracy and human rights. A practical guide to a socioculturally oriented, holistic approach to research in literacy programs, particularly with respect to community agencies and educational institutions, is provided by Hautecoeur (1991); Wagner (1989b) addresses quantitative and qualitative research techniques for community literacy agencies. 
A classroom practice with significant consequences for adult literacy programs is learner assessment. In this regard Librande and Jones (1987) provide a useful example of a test of adult functional literacy. Not surprisingly, this test closely resembles the National Literacy Secretariat/Statistics Canada (1990) test, discussed above, and thus the NAEP since Jones was the consultant to that survey. Jones (1989) has also provided an overview of standardized tests available to Canadian teachers of adult students, emphasizing the need to choose the right test for the right purpose.

\section{PLAIN LANGUAGE}

The plain language movement is active in Canada, but little formal material is published about it. One book about plain language and its context, by the Progressive Literacy Group (1986), not only details the actual creation of texts in plain language but also discusses social reasons why obfuscating text is often produced by sectors of society in positions of power. In light of the latter perspective, the authors refer to their goal not as plain language but as popular English. Another by Baldwin (1990) outlines how to recognize and use clear writing and how to convince others to use it. An example of material in plain language is Breen's book (1988) on women's health issues. Active centers in this field are the National Literacy Secretariat in Ottawa and the Plain Language Centre of the Canadian Law Information Council in Toronto. Publications on plain language, for public servants and the general public respectively, are expected from these organizations in the near future.

\section{CONLUSIONS}

Canadians now know more about adult literacy skills that can be tested in mass studies than almost any country in the world. It now behooves us to work out what all those data mean in terms of the literacy demands that Canadian society and institutions actually make on citizens. The data should also assist in determining the real needs for literacy as perceived by individuals, especially the poor and/or other special needs groups. Furthermore, Canadian researchers, along with their colleagues around the world, need to address seriously the vast literature on child literacy learning to see the extent to which its findings are relevant to adult literacy learning. Finally, those with primarily economic interests and those with main interests in social issues must at least attempt to cooperate in their research in order to come to grips with the real causes of, and means for, addressing adult illiteracy. 


\section{UNANNOTATED BIBLIOGRAPHY}

Anderson, E. 1989. Adult basic education programs in Canada. In M. Taylor and J. Draper (eds.) Adult literacy perspectives. Toronto: Culture Concepts, Inc. 95-102.

Association of Canadian Community Colleges. n.d. The national adult literacy database. London, Ontario: Fanshawe College.

Baldwin, R. 1990. Clear writing and literacy. Toronto: The Ontario Literacy Coalition.

Batdorf, L. 1991. A Canadian volunteer industrial tutoring project. In M. Taylor, G. Lewe and J. Draper (eds.) Basic skills for the workplace. Toronto: Culture Concepts, Inc. 333-347.

Bell, J. 1991. Becoming aware of literacy. Toronto: University of Toronto. Ph.D. diss.

(ed.) 1990. TESL Talk. 20.1. [A special issue on ESL literacy.]

Board of Education for the City of Toronto. 1985. The right to read. Toronto: The Board of Education for the City of Toronto.

Boucher, A. 1989. En toutes lettres et en français: l'analphabétisme et alphabétisation des francophones au Canada. [Written in full and in French: Illiteracy and literacy development of Francophones in Canada.] Montréal: L'Institut Canadien d'Éducation des Adultes at la Fédération des Francophones hors Québec.

Breen, M. 1988. Taking care: A handbook about women's health. Peterborough, Ontario: Young Women's Christian Association.

Burnaby, B. 1988. Community based ESL: An assessment of a federal pilot initiative. TESL Canada Journal. 6.1.27-39.

and R. Beaujot. 1986. The use of aboriginal languages in Canada: An analysis of 1981 census data. Ottawa: Social Trends Analysis Directorate and Native Citizens Directorate, Department of the Secretary of State.

(ed.) 1985. Promoting native writing systems in Canada. Toronto: OISE Press.

Cairns, J. 1988. Adult illiteracy in Canada. Toronto: Council of Ministers of Education, Canada.

Calamai, P. 1987. Broken words. Ottawa: Southam Newspaper Group.

Canadian Association for Adult Education. 1985. An analysis of the Statistics Canada Adult Education Survey. Toronto: Canadian Association for Adult Education.

Canadian Business Task Force on Literacy. 1988. Measuring the costs of literacy in Canada. Toronto: Canadian Business Task Force on Literacy.

Carver, R. 1989. Deaf illiteracy: A genuine educational puzzle or an instrument of oppression? A critical review. Ottawa: Canadian Association of the Deaf.

and D. Robar. 1990. Principles for a literacy curriculum for the deaf. Ottawa: Canadian Association of the Deaf. 
Cox, R. and L. Sanders. 1988. Canadian Woman Studies. 9.3/4. [Special double issues on women and literacy.]

Cranton, P. and J. Castle. 1990. Industrial tutoring project: Final report. St. Catharines, Ontario: Brock University.

Creative Research Group. 1987. Literacy in Canada: A research report. Ottawa: Southam Newspaper Group.

Cumming, A. and J. Gill. 1991. Motivation or accessibility? Factors in decisions of Indo-Canadian women to pursue ESL literacy instruction. Paper presented at the Annual Meeting of the American Educational Research Association. Chicago, April 1991.

Darville, R. 1989. The language of experience and the literacy of power. In M. Taylor and J. Draper (eds.) Adult literacy perspectives. Toronto: Culture Concepts, Inc. 25-40.

In press. The university and literacy: Trends in North America. In

L. Limage (ed.) Literacy and the role of the university. Paris: Unesco.

De Castell, S., A. Luke and D. MacLennan. 1986. On defining literacy. In S. de Castell, A. Luke and K. Egan (eds.) Literacy, society, and schooling: A reader. Cambridge, UK: Cambridge University Press. 3-14.

DesLauriers, R. C. 1990. The impact of employee illiteracy on Canadian business. Ottawa: Human Resource Development Center, Conference Board of Canada. [Report 58-90-E.]

Devereaux, M. 1985. One in every five: A survey of adult education in Canada. Ottawa: Statistics Canada and the Department of the Secretary of State.

Drouin, M-J. 1990. Workforce literacy: An economic challenge for Canada. Montreal: The Hudson Institute of Canada. [In English and French.]

Duncombe, B. and M. L. Fournier. 1987. Mother-tongue literacy: The bridge to learning. In M. Gayfer (ed.) Literacy in industrialized countries: A focus on practice. Toronto: International Council for Adult Education. 73-75. [In English and French.]

Economic Council of Canada. 1990. Good jobs, bad jobs: Employment in the service economy. Ottawa: Supply and Services Canada.

Fagan, W. 1987. Adult illiterates processing narrative and expository text. English Quarterly. 20.2.95-105.

Gaber-Katz, E. and G. Watson. 1989. Community-based literacy programming: The Toronto experience. In M. Taylor and J. Draper (eds.) Adult literacy perspectives. Toronto: Culture Concepts, Inc. 119-128.

G. Allan Roeher Institute. 1990. Literacy and labels: $A$ look at literacy policy and people with a mental handicap. Downsview, Ontario: G. Allan Roeher Institute.

Godin, J. 1991. Words of promise: Voluntary organizations' experiences with literacy. Ottawa: The National Literacy Secretariat.

Hagey, N., G. Larocque and C. McBride. 1989. Highlights of aboriginal conditions 1981-2001: Part III, Economic Conditions. Ottawa: Finance and Professional Services, Indian and Northern Affairs Canada. [Qualitative analysis and sociodemographic research working paper series 89-3.] 
Hautecoeur, J.-P. 1989a. Lectures critiques de l'analphabétisme. [Critical readings of illiteracy.] Education et Francophonie. 17.2.17-25.

1989b. Generous supply, barred demand: The current paradox of literacy. In M. Taylor and J. Draper (eds.) Adult literacy perspectives. Toronto: Culture Concepts, Inc. 129-141.

1991. Program-based research in literacy. Ottawa: National Literacy Secretariat. [In French and English.]

Hawrysh, B. 1991. How to identify workplace communication skills in the British Columbia sawmill industry. In M. Taylor, G. Lewe and J. Draper (eds.) Basic skills for the workplace. Toronto: Culture Concepts, Inc. 203-215. Horseman, J. 1990. Something in my mind besides the everyday: Women and literacy. Toronto: Women's Press.

Hughes, K. 1990. "You took my talk": Aboriginal literacy and empowerment. Fourth report of the Standing Committee on Aboriginal Affairs. Ottawa: House of Commons.

Jean, M. 1989. Implications of technological change for adult education. In M. Taylor and J. Draper (eds.) Adult literacy perspectives. Toronto: Culture Concepts, Inc. 113-118.

Jones C. and C. Brown. 1988. A personal story about learning and medication. Canadian Woman Studies. 9.3/4.69.

Jones, S. 1989. Tests for adult basic education and adult literacy. In M. Taylor and J. Draper (eds.) Adult literacy perspectives. Toronto: Culture Concepts, Inc. 217-225.

Klassen, C. 1987. Language and literacy learning: The adult immigrants' account. Toronto: University of Toronto. Masters diss.

Lewe, G. 1991. Understanding the need for workplace literacy partnerships. In M. Taylor, G. Lewe and J. Draper (eds.) Basic skills for the workplace. Toronto: Culture Concepts, Inc. 51-66.

Librande, L. and S. Jones. 1987. Ontario test of adult functional literacy. Ottawa: Carleton University.

Lloyd, B-A. 1991. Discovering the strength of our voices: Women and literacy programs. Toronto: Canadian Congress for Learning Opportunities for Women.

Lohnes, N. 1989. Remedial learning: An experiential approach. In M. Taylor and J. Draper (eds.) Adult literacy perspectives. Toronto: Culture Concepts, Inc. 293-299.

McBeth. S. 1989. Creating curriculum: A learner-centred approach. In M. Taylor and J. Draper (eds.) Adult literacy perspectives. Toronto: Culture Concepts, Inc. 145-153.

Miller, L. 1987. The approach of popular literacy groups in Quebec. In M. Gayfer (ed.) Literacy in industrialized countries: A focus on practice. Toronto: International Council for Adult Education. 31-35. [In English and French.]

1990. Illiteracy and human rights. Ottawa: National Literacy Secretariat. [In English and French.] 
Moore, A. and T. Westell. 1989. Voluntarism in community based literacy. In M. Taylor and J. Draper (eds.) Adult literacy perspectives. Toronto: Culture Concepts, Inc. 319-325.

National Literacy Secretariat and Statistics Canada. 1990. Survey of literacy skills used in daily activities. Ottawa: Statistics Canada.

Norman, C. and G. Malicky. 1986. Literacy as a social phenomenon: Implications for instruction. Lifelong Learning. 9.2.12-15.

O'Leary, J. D. 1991. Creating a love of reading. Ottawa: National Literacy Secretariat. [In English and French.]

Olson, D. 1988. The literacy problem: Myths and reality. The Globe and Mail. Toronto (August 15), A7.

One Voice, the Canadian Seniors' Network. 1989. Illiteracy and older Canadians: An unrecognized problem. Ottawa: One Voice, the Canadian Seniors' Network.

Ontario Public Health Association and Frontier College. 1989. Literacy and health project (phase one): Making the world healthier and safer for people who can't read. Toronto: Ontario Public Health Association and Frontier College. [In English and French.]

Progressive Literacy Group. 1986. Writing on our side. Vancouver: Progressive Literacy Group.

Rockhill, K. 1990. Literacy as threat/desire: Longing to be SOMEBODY. TESL Talk. 20.1.89-110.

Rubenson, K. 1989. The economics of adult basic education. In M. Taylor and J. Draper (eds.) Adult literacy perspectives. Toronto: Culture Concepts, Inc. 387-398.

Shuttleworth, D. 1989. Adult basic education and community development. In M. Taylor and J. Draper (eds.) Adult literacy perspectives. Toronto: Culture Concepts, Inc. 433-438.

Taylor, M. and G. Lewe. 1991. How to plan and conduct a literacy task analysis. In M. Taylor, G. Lewe and J. Draper (eds.) Basic skills for the workplace. Toronto: Culture Concepts, Inc. 217-235.

, G. Lewe and J. Draper (eds.) 1991. Basic skills for the workplace. Toronto: Culture Concepts, Inc.

Terry, W. In press. Unravelling the tangles: Learning information services for adults in Canada. Toronto: Learnxs Press.

Thomas, Alan, M. Taylor and C. Gaskin. 1989. Federal legislation and adult basic education in Canada. In M. Taylor and J. Draper (eds.) Adult literacy perspectives. Toronto: Culture Concepts, Inc. 41-56.

Thomas, Audrey. 1989. Definitions and evolution of the concepts. In M. Taylor and J. Draper (eds.) Adult literacy perspectives. Toronto: Culture Concepts Inc. 3-14. 1990a. The reluctant learner: A research report on nonparticipation and dropout in literacy programs in British Columbia. Victoria: British Columbia Ministry of Advanced Education, Training and Technology. 
Thomas, Audrey. 1990b. Encouraging adults to acquire literacy skills. Ottawa: Multiculturalism and Citizenship Canada.

Turk, J. and J. Unda. 1991. So we can make our voices heard: The Ontario Federation of Labour's BEST project on worker literacy. In M. Taylor, G. Lewe and J. Draper (eds.) Basic skills for the workplace. Toronto: Culture Concepts, Inc. 267-280.

Wagner, S. 1985. Illiteracy and adult literacy teaching in Canada; and analphabétisme et alphabétisation des adultes au Canada. Prospects 15.3.407417 [English version] and Perspéctives 15.3.447-458 [French version.] 1989a. L'alphabétisation et la recherche en français au Canada.

[Literacy development and research in French in Canada.] Revue Québecoise de Psychologie. 10.3.125-148.

$1989 \mathrm{~b}$. Field study of community literacy: Methodological questions. In M. Taylor and J. Draper (eds.) Adult literacy perspectives. Toronto: Culture Concepts, Inc. 235-254. and P. Grenier. 1990. Analphabétisme de minorité et alphabétisation d'affirmation nationale: $\dot{A}$ propos de l'Ontario français. Volume 1: Synthèse théorique et historique. [Minority illiteracy and literacy development of national affirmation: The case of Ontario French. Volume 1: Theoretical and historical synthesis.] Toronto: Ontario Ministry of Skills Development. [Alpha communataire chez les francophones 9.] White, J. and M. Norton. 1991. Whole language: A framework for thinking about literacy work with adults. Ottawa: National Literacy Secretariat. [In English and French.] 